асоціативний (демонстрація ідеї через візуальну метафору); підготовка телекомунікаційних проєктів, вироблення стратегії дистрибуції українського фільму; прийоми: «я в кіно» (вибір ролі, включаючи образи-речі, тварини, яку міг би зіграти студент), «лист одногрупнику» (надіслати кадри, кіноцитати, пояснити свій вибір), «драматизація фільму» (виступ у ролі актора; розповідь, відповіді на запитання від імені кіногероя), «стоп-кадр» (відтворення монологу героя, аналіз епізоду), «сам собі режисер» (опанування в ігровій формі теоретичних понять, як-от «екранізація», «кіномова»; ігрове кіно, «серіальна» адаптація твору, сценічна й кінематографічна версія образу героя тощо). Формуючи індивідуальне критичне судження про фільм, звертаємо увагу студентів на ймовірне використання авторами прийомів маніпулятивного впливу (наприклад, чи має значення для українського глядача те, що фільм В. Бортка «Тарас Бульба» за повістю М. Гоголя, профінансовано Міністерством культури Російської Федерації). Теми для колективних, проблемних обговорень, дискусій: «Чи має українське кіно втілювати спільну державну ідеологію, опиратися на українські традиції, цінності, мову?»; «Як узгодити відповідність кінопрезентації першоджерелу, письменницькому задуму 3 вимогами комерційних, популярних фільмів (ефектні сцени, спецефекти, відомі елітарні актори, «гламурність» зображення тощо)?»; «У наш час література впливає на кіно, чи кіно на літературу?»; «Чи погоджуєтеся Ви із твердженням, що «екранізація цілком справедливо вважається переходом прозового твору на вищий рівень»?» [2]; «Чи доречно рекомендувати для перегляду 3 навчальною метою фільми 3 еротичними сценами?»; «Який вихід із ситуації: культурно не підготовлений читач поповнює ряди культурно не підготовлених глядачів?».
Висновок. Отже, осмислення екранізацій у методичній перспективі пов'язане 3 моделюванням медіаосвітнього навчального процесу у вищій школі, інформатизацією освіти, застосуванням інтегрованого підходу до викладання літератури як реалізації міжпредметних зв'язків (педагогіка, літературознавство, кінознавство), трансформуванням знань у компетентності, зокрема створення мультимедійних аудіо- та відеооб'єктів, формуванням образного, критичного й аудіовізуального мислення.

Перспективи подальших наукових досліджень в означеному напрямі спрямовуватимуться на розроблення та апробацію методики медіаосвіти в закладах загальної середньої і вищої освіти, створення програм iз кіноосвіти для студентів філологічного факультету, а також розвиток рефлексії студентів щодо кінопродукції.

\section{СПИСОК ВИКОРИСТАНОЇ ЛІТЕРАТУРИ}

1. Брюховецька Л. Адаптація чи штурм літературного Евересту? Твори Івана Франка в кіно / Л. Брюховецька // Кіно - Театр. - 2006 - № 6. URL: http://ktm. ukma.edu.ua (дата звернення: 05.11.2019).

2. Кокотюха А. Українським авторам треба вчитися писати для кіно / А. Кокотюха. URL: http://detector. media/infospace/article (дата звернення: 03.10.2019).

3. Концепція впровадження медіаосвіти в Україні. URL: http://detector.media/mediaosvita (дата звернення: 05.11.2019).

4. Нежива Л. Одна сльоза котилася по лиці, як перла по скалі. Стильовий аналіз новели В. Стефаника «Камінний хрест» на тлі порівнянь 3 однойменним кінофільмом Л. Осики / Л. Нежива // Українська література в загальноосвітній школі. - 2012. - № 2. - С. 7-10.

Дата надходження до редакиіï: 11.12.2019 p.

\title{
МОЛОДІЖНИЙ СЛЕНГ У СУЧАСНІЙ АНГЛІЙСЬКІЙ ЛЕКСИКОЛОГІї
}

У статті проаналізовано проблеми розвитку молодіжного сленгу англійської лексикології. Окреслено деякі підходи до визначення сутності поняття «сленг». Висвітлено види молодіжного сленгу, охарактеризовано низку життєвих ситуацій, в яких сучасна молодь використовує сленгові слова та вирази.

Ключові слова: сленг, сленгові слова і вирази, молодіжний сленг, розмовна мова.

В статье проанализированы проблемы развития молодежного сленга английской лексикологии. Представлены некоторые подходы к определению сущчнсти понятия «сленг». Освешены виды молодежного сленга, охарактеризован ряд жизненных ситуаџий, в которых современная молодежь использует сленговые слова и выражения.

Ключевые слова: сленг, сленговые слова и выражения, молодежный сленг, разговорный язык.

The article analyzes the main problems of the development of youth slang in English lexicology. The basic approaches to the definition of the essence of the term "slang》 are presented. Different types of youth slang are presented and a number of life situations in which young people use slang expressions are characterized. 
The lexical composition of the English language, like any other language, contains a large number of slang entities that correspond to certain social and professional groups of people.

The variety of dialectisms, slangisms, etc., proves that language remains a dynamic, constantly evolving and evolving system. Slang has traditionally attracted the attention of domestic and foreign philologists due to the bright emotional and expressive coloring, conciseness and imagery of slangisms, the ability to constantly change the boundaries that divide it from the linguistic norm.

The study of these issues makes it possible to understand the tendency of language development in general, to look into its future, to show the problem of «language and its environment», which is important not only for social but also for «internal» linguistics.

Youth slang responds most vividly to all events in life. It picks up and reflects new phenomena, changes itself in the process of their transformation, and therefore has an effect on the use of spoken spoken language, which is communicating in everyday life, gradually displacing other vocabulary from use.

Youth slang in any language is the most interesting. It covers the basic interests of young people. Even as a person grows older, he continues to use slang expressions as a habit. So, the introduction of slang in older generation speech is ensured.

That is why the study of youth slang as an integral part of the national language is quite relevant.

Key words: slang, slang expressions, youth slang, spoken language.

Постановка проблеми. Не секрет, що спілкування для підлітків та молоді завжди було і залишається найважливішою сферою життєдіяльності. Однак, як відомо, мова сучасних молодих людей, зокрема i в Україні, викликає нині обурення вчителів, батьків, представників старшого покоління. Безперечно, $\epsilon$ про що турбуватися, адже за даними останніх досліджень, у молодіжному середовищі ступінь жаргонізації мови перевищує 50 \% для хлопців та 33 \% для дівчат, тобто молодіжний сленг наполовину витіснив літературні вирази.

Аналізуючи особливості англійського сленгу, зазначимо, що він багатофункціональний, адже збагачує мову іронічним ефектом. Включаючи майже третину всіх слів англійської мови, він має таку ж «містичну ауру», як незнайомі слова, вивчення яких сьогодні неабияк важливе. Без їхнього розуміння в сучасного покоління не буде розуміння самої мови, що несе за собою проблеми і в спілкуванні, і в розумінні моральних принципів народу-носія мови [4].

Чому ж молодь так часто вживає сленг? Передусім тому, що бажає бути сучасною, стильною, адже сленг має в собі відтінок відвертості, неформальності, виражає товариськість і легкість спілкування.

Молодіжний сленг, особливо україномовний, на жаль, ще не став предметом докладного аналізу. Це пов'язано насамперед із тим, що й досі в науці побутує негативне, заперечне ставлення до сленгу як периферійного, брутального, субстандартного явища лексико-семантичної системи мови, що не має права на вивчення та відповідну лексикографічну фіксацію.
Аналіз наукових досліджень і публікацій. Проблематика сленгу є предметом постійного наукового пошуку. Так, різноманітні аспекти молодіжного сленгу вивчали як вітчизняні (Л. Ставицька, О. Матвіяс, С. Мартос, О. Тараненко, О. Кондратюк, В. Радчук, Ю. Василенко, Л. Мацько та ін.), так і зарубіжні (I. Гальперін, Н. Тропіна, Т. Нікітіна, В. Хом'яков та ін.) мовознавці. Усі вони не лише досліджували термін «сленг» загалом, а й розглядали певні його особливості. При цьому недостатньо уваги приділяється розгляду сленгу як перекладознавчої проблеми. У зв'язку 3 цим варто виокремити наукові праці І. Бик, О. Лапової, Т. Холстиної та ін.

Представлені нами праці варто також доповнити словниками Баумана, Хоттена, Партріджа, Берка, де словам-сленгізмам, насамперед у мові письменників та літераторів, приділяється значна увага,

Ураховуючи актуальність та недостатній стан розробки означеної проблеми, мета нашого дослідження полягає в аналізі теоретичних і практичних підходів до поняття сленгу як різновиду соціальних діалектів в англійській лексикології, основних тенденцій його розвитку та причин поширення серед молоді.

Виклад основного матеріалу. Відомий мовознавець, укладач словника сленгу Ерік Партрідж, зауважує: «Сленг існує 3 давніх-давен, оскільки люди завжди намагаються урізноманітнити мову більш жвавими, яскравими словами, замінити незрозумілі наукові терміни словами, доступнішими для широкого кола людей» [8]. Тож грунтовніше підійдемо до даного питання та з’ясуємо, що ж таке «сленг».

Великий тлумачний словник сучасної української мови пропонує таке визначення терміна «сленг»-розмовний варіант професіонального мовлення, жаргон; жаргонні слова або вирази, характерні для мовлення людей певних професій або соичіальних прошарків, які, проникаючи в літературну мову, набувають помітного емоиійно-експресивного забарвлення [1, с. 1147].

Щодо англійського мовознавства, то тут до сленгу підхід трохи інший, наприклад, спостерігається чітке розмежування термінів «жаргон» і «сленг», хоча ці слова нерідко й взаємозамінюються. Так, в англомовній лінгвістиці термін «сленг» прийнято використовувати на позначення некодифікованої мови, але проблема полягає не лише в тому, щоб відділити сленг від жаргону, а передусім - щоб зафіксувати перехід слів зі сленгу в розмовне мовлення та літературну мову.

Проблематика сленгу є предметом постійного наукового пошуку. На жаль, єдиного визначення поняття «сленг» на сьогодні не існує, а отже, кожен учений чи науковець, що цікавиться даною цариною, підходить до нього $з$ власного погляду. Так, Л. Ставицька під терміном «сленг» розуміє «мовне середовище спілкування значної кількості людей, яке відрізняється від мовної норми» [5, с. 40]. Провідний британський сленголог Е. Партрідж вбачає в сленгу «наявні в розмовній сфері досить нестійкі й некодифіковані, а іноді й узагалі безладні й випадкові сукупності лексем, що відображають суспільну свідомість людей, які належать до певного професійного чи соціального середовища» [8], a американський лінгвіст Ч. Фріз переконаний, 
що «сучасний сленг має настільки широкі межі й використовується для позначення значної кількості понять, що майже неможливо достеменно визначити, що є сленгом, а що - ні» [7, с. 52]. Науковець В. Хомяков, який одним із перших комплексно підійшов до питання сленгу в англістиці, виокремлює сленг як «відносно стійкий у певний період, широко вживаний, стилістично маркований, експресивний лексичний пласт (іменники, прикметники та дієслова, що позначають різноманітні побутові явища, предмети, процеси й ознаки), який хоча і $є$ частиною літературної мови, однак доволі неоднорідною за ступенем наближення до літературного стандарту» [6, с. 43-44].

Зважаючи на вищевикладене, термін «сленг» у сучасній англійській лексикології можна трактувати по-різному:

- ефемерні лексеми, що використовуються певними соціальними групами (субгрупами), яким притаманна швидка змінюваність;

- нелітературна лексика (сленгізми), яка перебуває «за межами» літературної англійської мови (Standard English, King's English) з погляду вимог сучасної літературної норми;

- лексика, що виникла і вживається передусім в усному мовленні;

- специфічна мова спілкування людей певних професій та вікових груп тощо.

При всій повазі до літературної мови, важко заперечити той факт, що сленг, незважаючи на його дещо фамільярну і навіть вульгарну форми, - найяскравіше, найемоційніше і найжвавіше явище в мові, що першим реагує на будь-які зміни в житті людей, особливо молодих, а також допомагає їм якнайглибше висловити свої думки та почуття.

Дослідивши етимологію та основні підходи лінгвістів до визначення поняття «сленг», нами було встановлено, що існують такі його різновиди: професійний сленг, кримінальний сленг, сленг певної сфери діяльності, сленг соціального статусу, віковий сленг.

До основних причин використання сленгових утворень відносимо: соціальний розвиток, технічний прогрес, нові «віяння» в культурі, що сприяють розвитку сленгу, який являє собою значний прошарок розмовної мови та має тенденцію швидко трансформуватися, постійно змінюватися та оновлюватися.

Розрізняють два види сленгових лексичних одиниць: загальний сленг - слова та словосполучення, що не є специфічними для певної соціальної чи професійної групи, тобто загальнозрозумілими; спеціальний сленг - слова та словосполучення тієї чи іншої соціальної або професійної групи, наприклад, сленг студентів, сленг футбольних фанатів, сленг моряків та школярів.

Для того, щоб отримати цілісне уявлення про сленг, розглянемо американський варіант англійської мови, який відносили до сленгу англійської мови досить тривалий час. Для нього, як зазначають учені Ю. Волошин та М. Маковський [2; 3], характерна своєрідна яскравість, емоційність та експресивність, а загальнолітературна розмовна лексика переходить у нелітературну настільки плавно і непомітно, що межу між ними встановити надзвичайно важко.
Молодіжний сленг у будь-якій мові - надзвичайно цікаве явище, адже охоплює насамперед інтереси молоді. Навіть подорослішавши, людина за звичкою продовжує вживати сленгові вирази, які згодом непомітно входять у мовлення старшого покоління. У зв'язку з цим особливою своєрідністю відзначається американський студентський сленг, який, однак, не притаманний офіційному мовленню. Сюди можна віднести знижені дублети-синоніми на кшталт: roaddog, dude, boogerhead = chap, pal, fellow, buddy, guy, chum, mate - товариш, приятель, друг; wench, gooey = girlfriend - подруга, кохана дівчина; bank, yen, duckets, spent, bones, Benjamin, loot = money гроші, бабки, зелені; buttons = remote control device for $\boldsymbol{I V}$ - пульт дистанційного управління для телевізора; posse, dogpack, trite, crew = one circle of friends - коло друзів; to bum = ask - просити; buzz crusher = killjoy - зануда, людина, яка псує задоволення іншим; to jack = to steal - красти; to jet, jam = to leave, to go - йти; janky = unattractive, not stilysh - непривабливий; jewels = a very nice pair of shoes - дуже гарна пара взуття; to lunch = to go crazy збожеволіти [10].

Особливої уваги заслуговує та частина студентського сленгу, яку відносять до емоційно забарвленої лексики (найчастіше іронічного чи пародійного характеру), наприклад: cuenvobe bacon ma police - поліцейський; beef = problem - проблема; buffalo chick = fat female - товста жінка; mule with a broom $=$ a very udly girl - дуже негарна дівчина; business class = fat, too large to fit in a normal sized seat - надто товстий, щоб поміститись на звичайному сидінні; dark side = the student neighborhood - студентський район; fruit = a looser, stupid person - дурник [10]. Отже, у створенні цих одиниць значну роль відіграє метафоричне перенесення.

Як відомо, молодь використовує значну кількість різноманітних сленгізмів, спілкуюючись у соціальних мережах, спеціальних мобільних додатках, надсилаючи звичайні «есемески» чи електронні листи. Серед найбільш поширених і широко розповсюджених інтернет-сленгізмів:

- ASAP (As Soon As Possible). This work has to be made asap. - Ця робота потрібна якнайшвидше;

- KTHX (OK, Thanks) - дякую, спс; даний сленгізм зазвичай використовують для завершення нецікавої бесіди, наприклад:

- A: Hey, sup' bro?

- B: KTHX.

- А: Як життя, чувак?

- В: Все норм, спс.

- GR8 (скорочена форма слова Great) - чудово. Наприклад: That looks gr8 - мати чудовий вигляд;

- ОТОН (акронім вid On the Other Hand) 3 іншого боку. Наприклад: I don't really like chocolate. OTOH, it can really cheer me up when I'm feeling down. - Я взагалі не люблю шоколад, але, 3 іншого боку, він піднімає мені настрій, коли я засмучений;

- ROFL (акронім вid Roll On the Floor Laughing) ржу не можу, бугага, качатись по підлозі зі сміху. Наприклад: That joke left me ROFL! - Я валявся 3 цього жарту [9]. 
Деякі сленгові вислови використовуються молоддю, щоб підкреслити позитивні риси людини. Так, для того, щоб описати красиву дівчину, можна використати слова peach (персик), vamp (жінка-вамп), gold-digger (золотко). Якщо ж у розмові $є$ потреба згадати друга, з яким знайомий ще зі шкільної парти, то поняття «friend» можна замінити на «ace» (добрий товариш, дружбан). А от описуючи зовнішність людини, варто пам'ятати, що слово "face» має безліч синонімів, як-от: "smiler», "snoot», «kisser», «dish», «mask». Вони зовсім не образливі, а отже, молодь часто використовує їх, спілкуючись із друзями.

Звичайно, кожній молодій людині хочеться бути не лише фінансово незалежною (у цьому випадку на позначення грошей $є$ особливі слівця: «сabbage» (капуста), «bob» (шилінг), «dough» (гроші)), а й першою в усьому (для цього навіть потрібний вислів $є$ : «ahead of the game» (бути кращим, бути першим)) [9].

Як бачимо, молодь вживає чимало сленгізмів для опису різних життєвих ситуацій, свого фізичного стану тощо. Їх адекватний переклад українською мовою дає змогу впливати на цільову аудиторію так само, як на неї впливає текст оригіналу. У зв'язку 3 цим варто пам'ятати: використовуючи сленгову лексику, слід бути впевненим у тому, що вона коректно перекладена.

Одним із основних і найбільш ефективних способів перекладу молодіжного сленгу $є$ пошук функціональних аналогів. Однак, зважаючи на територіальні, культурні та національні відмінності між англійцями та українцями, аналоговий переклад значної кількості сленгізмів суттєво ускладнюється. Крім того, суттєвою перепоною під час перекладу за допомогою функціонального аналогу $є$ те, що український молодіжний сленг, на відміну від англійського, по-суті, перебуває на етапі свого становлення. У разі відсутності функціонального аналогу перекладач може вдатися до описового перекладу, але при цьому йому не слід забувати, що сленг, особливо молодіжний, відзначається емоційно-експресивним забарвленням, яке при описовому перекладі втрачається.

Ознайомлення 3 доволі розлогим переліком наукової перекладацької літератури дає підстави визначити серед основних труднощів, з якими людина стикається під час перекладу молодіжного сленгу, такі:

- складність правильного декодування значення сленгізмів;

- відсутність функціональних аналогів до багатьох англійських сленгізмів, що вимагає звернення до описового перекладу або формування нових слів із метою збереження стилістичної забарвленості;

- потреба в обізнаності щодо культурних, історичних, територіальних особливостей країни походження сленгу;

- швидкість заміщення одних сленгізмів іншими.

Чи можна оволодіти молодіжним сленгом? Звичайно, так! Але для цього потрібно постійно перебувати в молодіжному середовищі, в якому розмовляють англійською мовою (саме це дає можливість не лише чути потрібні вирази, а й самому спілкуватися, використовуючи в розмові сленгові вирази), постійно повторювати сленгізми вдома, а також звіряти їхній переклад зі словником сленгу.

Висновки. Підсумовуючи вищевикладене, можемо зробити висновок, що роль сленгу в житті молоді відіграє неабияку роль, адже при спілкуванні молоді люди вживають його не лише для передачі інформаціï, а й для вираження власного світогляду, ідей, а також для підкреслення власної особистості та того, що вони «йдуть у ногу з часом».

Вивчення сленгу американського варіанту сучасної англійської мови дозволило нам класифікувати сленгові утворення за сферою вживання, а ще з'ясувати, що він часто виконує важливу соціальну функцію, яка полягає у «виключенні» або «включенні» людини в певне оточення, вживання тієї мови, яка функціонує в певному колі людей чи в певній професії.

Отже, сленг - це не лише лексична інновація, а й найбезпечніший і найефективніший спосіб протесту проти встановлених догм і правил.

\section{СПИСОК ВИКОРИСТАНОЇ ЛІТЕРАТУРИ}

1. Великий тлумачний словник сучасної української мови / уклад. і гол. ред. В. Т. Бусел. - Київ = Ірпінь : Перун, 2007. - 1736 с.

2. Волошин Ю. Общий американский сленг: состав, деривация и функция / Ю. Волошин. - К., 2000. C. 5.

3. Маковский М. М. Современный английский сленг: онтология, структура, этимология : [пособие] / М. М. Маковский. - Изд. 3-е. - М. : URSS. ЛКИ, 2007. - 164 c.

4. Підгорець А. В. Культура мовлення та молодіжний сленг (на матеріалі англійської мови) як засіб відображення світогляду особистості / А. В. Підгорець. URL: https://www.psyh.kiev.ua/ (дата звернення: 18.11.2019).

5. Ставицька Л. О. Арго, жаргон, сленг. Соціальна диференціація української мови / Л. О. Ставицька ; [відп. ред. В. В. Німчук]. - Київ : Критика, 2005. $464 \mathrm{c}$.

6. Хомяков В. А. Нестандартная лексика английского языка / В. А. Хомяков. - Москва : Либроком, 2010. - $138 \mathrm{c}$.

7. Fries Ch. Introduction to American College Dictionary / Ch. Fries. - New York, 1947. - 358 p.

8. Partrige E. Slang To-Day And Yesterday / E. Partrige. - London : Routledge and Kegan Paul, 1970. $484 \mathrm{p}$.

9. The Oxford Dictionary of New Words. Mode of access. URL: http://public.oed.com/the-oed-today/ recent-updates-to-the-oed/september-2017-update/ new-words-list-september-2017/ (дата звернення: 10.11.2019).

10. Urban Dictionary - Mode of access. URL: https://www.urbandictionary.com/ (дата звернення: 10.11.2019).

Дата надходження до редакиії: 26.12.2019 p. 